\title{
Opioid Actions on Rat Anterior Cingulate Cortex Neurons in vitro
}

\author{
Eiichiro Tanaka a and R. Alan North \\ Vollum Institute, Oregon Health Sciences University, Portland, Oregon 97201
}

Intracellular recordings were made from layer $\mathbf{V}$ pyramidal neurons in slices of rat anterior cingulate cortex, using electrodes that contained potassium methylsulfate and biocytin. [Met ${ }^{5}$ ]enkephalin (300 nm to $30 \mu \mathrm{M}$ ) reversibly reduced the amplitude of EPSPs evoked by stimulation of the subcortical white matter; the half-maximal concentration was about 800 nM. These EPSPs were blocked by $( \pm)$-2-amino-5-phosphonovaleric acid and 6-cyano-7-nitroquinoxaline-2,3-dione. [Met ${ }^{5}$ ]enkephalin also reduced the amplitude of bicucullinesensitive IPSPs evoked by stimulation within layer $\mathbf{V}$; the half-maximal concentration was about $60 \mathrm{~nm}$. Both these actions of $\left[\mathrm{Met}^{5}\right]$ enkephalin were mimicked by the $\delta$-selective agonist DPDPE (Tyr-D-Pen-Gly-Phe-D-Pen) but not by the $\mu$-selective agonist DAMGO (Tyr-D-Ala-Gly-MePhe-Gly-ol); they were blocked by the $\delta$-selective antagonist naltrindole (apparent dissociation constant of about $0.3 \mathrm{~nm}$ ) but not by the $\mu$-selective antagonist CTOP (D-Phe-Cys-Tyr-D-Trp-OrnThr-Pen-Thr-NH ${ }_{2}$ ). [Met ${ }^{5}$ ]enkephalin did not change the amplitudes of depolarizations evoked by direct application of glutamate or hyperpolarizations evoked by direct application of muscimol (at $-55 \mathrm{mV}$ ). Fifty percent (22 of 45 ) of pyramidal cells were hyperpolarized by [Met $\left.{ }^{5}\right]$ enkephalin; this resulted from an increase in potassium conductance, and it was mimicked by DPDPE and blocked by naltrindole. Five of seven nonpyramidal cells were hyperpolarized by [Met $\left.{ }^{5}\right]$ enkephalin; this was mimicked by DAMGO and blocked by CTOP. It is concluded that activation of $\delta$-opioid receptors hyperpolarizes some pyramidal neurons in the prefrontal cortex, and also inhibits presynaptically the release of excitatory amino acids and GABA at synapses onto pyramidal neurons. Activation of $\mu$-opioid receptors hyperpolarizes nonpyramidal neurons but does not inhibit the release of excitatory amino acids or GABA onto pyramidal neurons.

[Key words: opioid receptors, synaptic potentials, anterior cingulate cortex]

The actions of morphine at the cellular level were first investigated in the neocortex (Krnjević, 1965), but in the intervening years there has been "no systematic study of the effects of ligands, having high specificity for different opiate receptors, on

Received Apr. 12, 1993; revised July 26, 1993; accepted July 29, 1993.

This work was supported by Grants DA03160, DA03161, and MH40416 from the U.S. Department of Health and Human Services, and Glaxo Group Research.

Correspondence should be addressed to Dr. R. A. North, Glaxo Institute for Molecular Biology, 14 chemin des Aulx, 1228 Plan-les-Ouates, Geneva, Switzerland.

a Present address: Department of Physiology, Kurume University School of Medicine, 67 Asahi-machi, Kurume, 830 Japan.

Copyright (C) 1994 Society for Neuroscience $0270-6474 / 94 / 141106-08 \$ 05.00 / 0$ neurones of the cerebral cortex" (Duggan and Fleetwood-Walker, 1992). There are three types of reasons why an increased understanding of opiate actions in the anterior cingulate cortex is desirable. First, morphine and its congeners produce mood alterations such as a feeling of tranquility. The cellular substrates for these effects are not understood but there is electroencephalographic evidence for direct cortical involvement (reviewed Duggan and North, 1984; Duggan and Fleetwood-Walker, 1992). Second, opioid drugs selective for $\mu$-receptors are strongly reinforcing, and this probably involves the dopamine projections from the midbrain to the nucleus accumbens and cingulate cortex (DiChiara and North, 1992; Koob, 1992). Third, three types of opioid receptor, as well as endogenous opioid peptides, are present in the cerebral cortex (reviewed Mansour and Watson, 1992). Although there are regional and species differences, $\delta$-receptors and [Leu $\left.{ }^{5}\right]$ enkephalin immunoreactivity are diffusely distributed in layers II, III, V, and VI, whereas $\mu$-receptors are most prominent in layers I and III/IV (McGinty et al., 1984; Mansour et al., 1987, 1988; Blackburn et al., 1988; Mansour and Watson, 1992). The physiological role of the endogenous opioids remains obscure.

In several other parts of the nervous system, opiates acting at $\mu$ - and $\delta$-receptors have two main direct cellular actions that are readily detectable electrically (North, 1992). First, they inhibit action potential firing by increasing the membrane potassium conductance. Where synaptic connections among cells are intact, such inhibition of interneurons can lead to excitation of other cells; this is seen in hippocampal pyramidal cells (Zieglgänsberger et al., 1979; Madison and Nicoll, 1988) and dopamine-containing neurons of the ventral tcgmental arca (Johnson and North, 1992). Second, opioids reduce voltage-dependent calcium currents (reviewed by North, 1992). In many parts of the CNS and PNS opioids reduce the release of neurotransmitters (Illes, 1989) but, in most cases, it remains unclear whether inhibition of transmitter release is causally related to the effects on potassium and calcium channels (e.g., Cohen et al., 1992).

The aim of the present work was to determine the actions of opioids selective for $\mu$ - and $\delta$-receptors on neurons of the rat anterior cingulate cortex. Intracellular recording was used so that the neurons could be labeled for subsequent histology. Synaptic potentials mediated by excitatory amino acids and GABA were isolated pharmacologically; their amplitudes were used, with appropriate controls, as indices of the effects of opioids on transmitter release.

\section{Materials and Methods}

The methods have been described previously (Tanaka and North, 1993). Briefly, rats were killed under deep halothane anesthesia by severing the great vessels of the chest. The brain was removed and a block of tissue that contained the anterior cingulate cortex was sectioned with a 

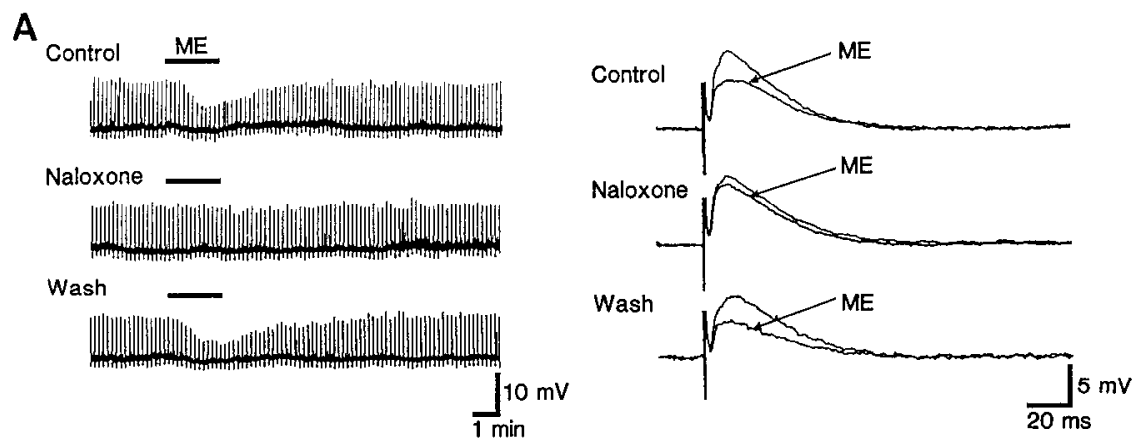

B

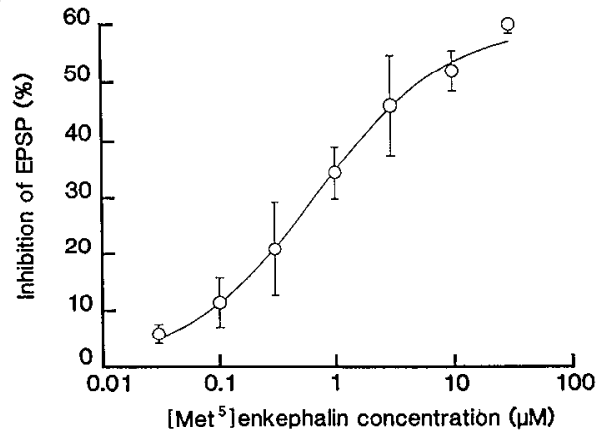

Figure 1. [Met $\left.{ }^{5}\right]$ enkephalin inhibits the EPSP. A:Left, Time course of inhibition. Upward deflections are EPSPs. [Met ${ }^{5}$ ]enkephalin $(M E ; 10 \mu \mathrm{M})$ was applied during the time indicated by the horizontal bar. The middle record shows that the effect of $\left[\mathrm{Met}^{5}\right]$ enkephalin was blocked by naloxone $(1 \mu \mathrm{M})$; the lower record is after the washout of naloxone. Right, Each panel shows the control EPSP superimposed on the EPSP in [Met ${ }^{5}$ ]enkephalin $(10 \mu \mathrm{M})$. Each EPSP shown is the average of 10 . Top, Synaptic potentials were reduced by [Met ${ }^{5}$ lenkephalin $(M E ; 10 \mu \mathbf{M}, 2 \mathrm{~min})$. Middle, Naloxone blocked the effect of $\left[\mathrm{Met}^{5}\right.$ ]enkephalin. Bottom, Wash of naloxone. Membrane potential was -70 mV. $B$, Concentration dependence of inhibition. Each point shows the mean $\pm \mathrm{SD}$ of three to eight cells tested at each concentration. Bicuculline (500 nM) was present throughout. Synaptic potentials were evoked by stimulation of subcortical white matter. vibratome $(350 \mu \mathrm{m})$. The tissue slice was submerged in a flowing physiological saline that contained (mM) NaCl, 126; $\mathrm{KCl}, 2.5 ; \mathrm{CaCl}_{2}, 2.4$; $\mathrm{MgCl}_{2}, 1.2 ; \mathrm{NaH}_{2} \mathrm{PO}_{4}, 1.2 ; \mathrm{NaHCO}_{3}, 26 ;$ dextrose, 10 (saturated with $95 \% \mathrm{O}_{2}, 5 \% \mathrm{CO}_{2} ;$ preheated to $36^{\circ} \mathrm{C}$ ). Intracellular recordings were made from neurons within layer $\mathrm{V}$, using electrodes that contained potassium methylsulfate ( $2 \mathrm{M}$ ) and biocytin $(20 \mathrm{mg} / \mathrm{ml}$ in $10 \mathrm{~mm}$ Tris buffer at $\mathrm{pH}$ 7.2). Tissues were fixed after the recordings in Zamboni fixative, incubated with extravidin-peroxidase conjugate, and reacted with diaminobenzidine $(5 \mathrm{mg} / \mathrm{ml}$ in $0.01 \%$ hydrogen peroxide). Focal electrical stimulation was applied using two tungsten-in-glass electrodes; these were placed on the surface of the subcortical white matter or within layer $\mathrm{V}$. The components of the synaptic potentials mediated by excitatory amino acids (hereafter referred to as glutamate) and mediated by GABA were isolated with receptor antagonists (see Tanaka and North, 1993). Bicuculline ( $500 \mathrm{nM}$ ) was used to isolate the glutamate component and ( \pm )-2-amino-5-phosphonovaleric acid (APV; $50 \mu \mathrm{M}$ ) and 6-cyano7-nitroquinoxaline-2,3-dione (CNQX; $10 \mu \mathrm{M}$ ) were added to isolate the GABA component. Drugs were applied by changing the superfusing solution. They included [Met $\left.{ }^{5}\right]$ enkephalin, Tyr-D-Ala-Gly-MePhe-Glyol (DAMGO), Tyr-D-Pen-Gly-Phe-D-Pen (DPDPE), Tyr-D-Ala-Gly-PheD-Leu (DADLE), trans-( \pm )-3,4-dichloro- $N$-methyl-[2-(1pyrrolidinyl)cyclohexyl]benzeneacetamide $(\mathrm{U} 50488 \mathrm{H})$, naltrindole hydrochloride, D-Phe-Cys-Tyr-D-Trp-Orn-Thr-Pen-Thr-NH $\mathrm{N}_{2}$ (CTOP), naloxone, L-glutamate, and muscimol. Glutamate and [ $\left.\mathrm{Met}^{\mathrm{s}}\right]$ enkephalin were also applied by pressure ejection; a few nanoliters of a solution containing $500 \mathrm{~mm}$ glutamate or $10 \mathrm{~mm}$ [Met $\left.{ }^{5}\right]$ enkephalin were ejected by a pulse of pressure from a glass micropipette, the tip of which (2-5 $\mu \mathrm{m}$ ) was positioned beneath the surface of the superfusing solution and above the tissue slice. The reductions of amplitude of the synaptic potentials by different concentrations of opioid agonists are expressed as percentages (mean \pm standard deviation). Equilibrium dissociation constants for naltrindole $\left(K_{D}, \mathrm{nM}\right)$ were estimated for individual neurons from $K_{D}=3 /(\mathrm{DR}-1)$, where DR is the ratio by which the agonist concentration had to be increased to obtain the same percentage inhibition in the presence of $3 \mathrm{~nm}$ naltrindole. This assumes that naltrindole acted as a competitive antagonist (Portoghese et al., 1988); in a few cells to which several concentrations of naltrindole were applicd they produced increasing rightward shifts in the concentration-response curve for $\left[\mathrm{Met}^{5}\right]$ enkephalin (see Figs. 3,6 ).

\section{Results}

The 52 neurons included in this study had resting membrane potentials of $-66 \pm 6.5 \mathrm{mV}$ (mean $\pm \mathrm{SD}$ ) and input resistances [measured from the amplitude of small $(<10 \mathrm{mV})$ hyperpolarizing electrotonic potentials] of $58 \pm 23 \mathrm{M} \Omega$. Histological examination allowed the cells to be classed as pyramidal or nonpyramidal (see Tanaka and North, 1993); in this study 45 cells were pyramidal neurons (input resistance of $53 \pm 19 \mathrm{M} \Omega$ ) and 7 cells were nonpyramidal neurons (input resistance was $93 \pm$ $23 \mathrm{M} \Omega$ ).

\section{Inhibition of the synaptic potential mediated by glutamate}

[Met ${ }^{5}$ ]enkephalin (30 $\mathrm{nM}$ to $30 \mu \mathrm{M}$ ) reduced the amplitude of EPSPs elicited by electrical stimulation of subcortical white matter (in bicuculline $500 \mathrm{~nm}$ ) (Fig. 1). The effect developed within 1-2 min of $\left[\mathrm{Met}^{5}\right]$ enkephalin reaching the recording chamber and reversed fully when the tissue was washed with control solution for 5-15 min. The inhibition of the EPSP persisted as long as the $\left[\mathrm{Met}^{5}\right]$ enkephalin application was continued (up to $10 \mathrm{~min}$ ) with no change in the degree of inhibition. Similar results were observed with stimulation in layer $V$, and [Met ${ }^{5}$ ]enkephalin was equally effective at depressing the EPSP generated from either site when this was compared in the same cell. The minimal effective concentration of $\left[\mathrm{Met}^{5}\right]$ enkephalin was $30 \mathrm{nM}$, and the EPSP was inhibited by $60 \pm 1.6 \%(n=7)$ with a concentration of $30 \mu \mathrm{M}$ (Fig. 1). The effect of $\left[\mathrm{Met}^{5}\right]$ enkephalin on the EPSP was not different in neurons that were hyperpolarized (see below) and those that were not.

The reduction of the EPSP by [ $\left.\mathrm{Met}^{5}\right]$ enkephalin was mimicked by DPDPE (Fig. 2) and by [D-Ala ${ }^{2}$ deltorphin-II, which are agonists selective for $\delta$-receptors. DPDPE (100 nM, $3 \mathrm{~min}$ ) reduced the EPSP amplitude by $39 \pm 9.4 \%(n=8)$ of control, and [D-Ala ${ }^{2}$ ]deltorphin-II (100 nM, 3 min) reduced the EPSP amplitude by $33 \pm 1.0 \%(n=3)$. The effect was reversibly blocked by naloxone ( $1 \mu \mathrm{M}, 10 \mathrm{~min}$ ) (Fig. $1 A$ ) and by naltrindole (1-10 nM) (Fig. 3), which is an antagonist selective for $\delta$-receptors. Naloxone (1 $\mu \mathrm{M}, 10 \mathrm{~min})$ reduced the inhibition of the EPSP by [Mct ${ }^{5}$ ]cnkcphalin $(10 \mu \mathrm{M})$ from $40 \pm 5.3 \%(n=6)$ to $13 \pm 1.8 \%(n=6)$ (Fig. 1$)$. Naltrindole $(10 \mathrm{nM})$ reduced the 
A
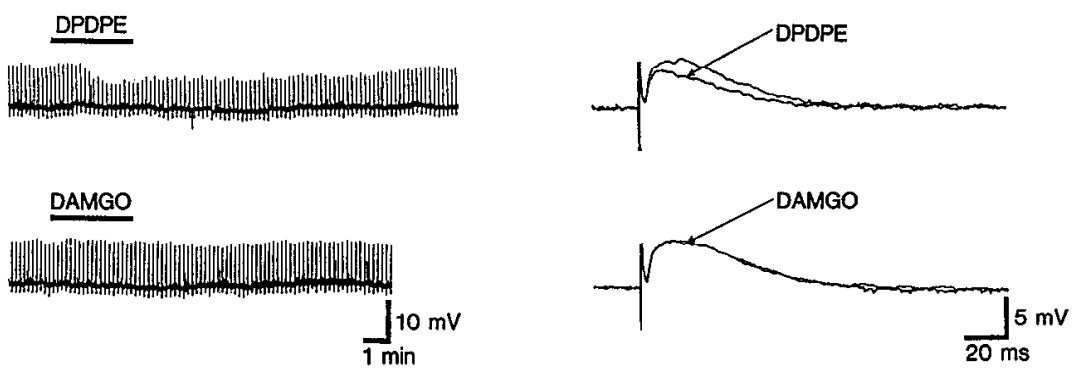
Figure $2 . \quad \delta$-Receptor-selective ago-
nist inhibits the EPSP. $A$, Synaptic potentials were inhibited by DPDPE (1 $\mu \mathrm{M})$ but not by DAMGO $(1 \mu \mathrm{M})$. Details are as for Figure 1. Resting potential was $-72 \mathrm{mV} . B$, Depolarization evoked by glutamate $(500 \mathrm{~mm}, 140 \mathrm{kPa}$ for 30 $\mathrm{msec}$ ) was unaffected by [Met $\left.{ }^{5}\right]$ enkephalin. Left, Control. Middle, In [Met ${ }^{5}$ ]enkephalin $(M E ; 10 \mu \mathrm{M})$. Right, Wash. Resting potential was $-75 \mathrm{mV}$. Synaptic potentials were induced by stimulation to subcortical white matter; bicuculline ( $500 \mathrm{~nm}$ ) was present.

\section{B}

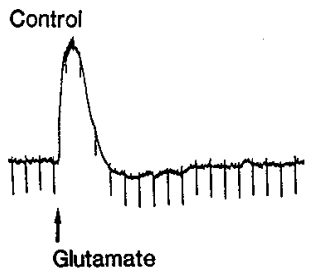

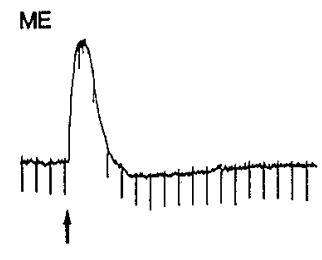

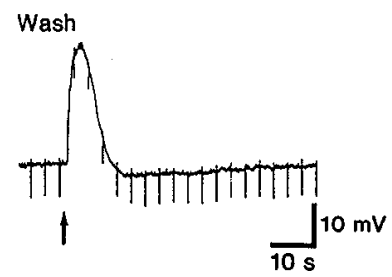

inhibition of the EPSP amplitude by [Mets]enkephalin $(10 \mu \mathrm{M})$ from $52 \pm 3.4 \%(n=5)$ to $18 \pm 0.9 \%(n=5)$. Agonists selective for $\mu$-receptors (DAMGO, $3 \mu \mathrm{M}, n=5$ ) (Fig. 2) and $\kappa$-receptors (U50488, $1 \mu \mathrm{M}, n=5$ ) had no effect on the EPSP; CTOP (300 nM), an antagonist at $\mu$-receptors, did not alter the inhibition caused by [Met ${ }^{s}$ ]enkephalin $(10 \mu \mathrm{M})$. Increasing concentrations of naltrindole produced rightward shifts of the concentrationeffect curves for $\left[\mathrm{Met}^{5}\right]$ enkephalin (Fig. 3). The apparent dissociation constant for naltrindole was calculated on the assumption that the antagonism between naltrindole and $\left[\mathrm{Met}^{5}\right]$ enkephalin was competitive; it was $0.31 \pm 0.18 \mathrm{nM}(n=$ 8).

Both the non-NMDA and NMDA components of the EPSP were similarly depressed by DPDPE. In four cells, the EPSP was reduced to $39 \pm 5.2 \%$ of control by DPDPE (100 nM); after adding $\Lambda \mathrm{PV}(50 \mu \mathrm{M})$, the remaining non-NMDA component was reduced to $44 \pm 3.7 \%$ of control. After washing out the APV, CNQX (10 $\mu \mathrm{M})$ was added; DPDPE reduced the NMDA component to $36 \% \pm 1.2 \%$ of control. Glutamate was applied by pressure ejection and it evoked a depolarization of 10-30 $\mathrm{mV}$. [Met ${ }^{5}$ ]enkephalin $(10 \mu \mathrm{M})$ did not affect the response to glutamate $(n=6)$ (Fig. 2$)$. The same results were obtained with $(n=5)$ or without $(n-3)$ bicuculline $(500 \mathrm{~nm})$, and with $(n=$ 4) or without $(n=3)$ TTX $(1 \mu \mathrm{M})$.

\section{Inhibition of the synaptic potential mediated by GABA}

[Met ${ }^{5}$ ]enkephalin ( $30 \mathrm{nM}$ to $10 \mu \mathrm{M}$ ) reduced the amplitude of the fast IPSP elicited by electrical stimuli to layer V (in $50 \mu \mathrm{M}$
Figure 3. Naltrindole competitively antagonizes inhibition of EPSP (recordings from a single cell). $A$, Each panel shows two superimposed traces (each the average of 10 EPSPs) before and after adding [Met'] enkcphalin. Left, Increasing concentrations of $\left[\mathrm{Met}^{5}\right]$ enkephalin (indicated in $\mu \mathrm{M}$ ) increasingly inhibit the EPSP. Right, in the presence of naltrindole (10 nM). $B$, The effects of [Met ${ }^{s}$ enkephalin applied to this cell on 19 occasions. Numbers beside the curves indicate the concentrations of naltrindole present (nM). Bicuculline (500 nM) was present throughout.
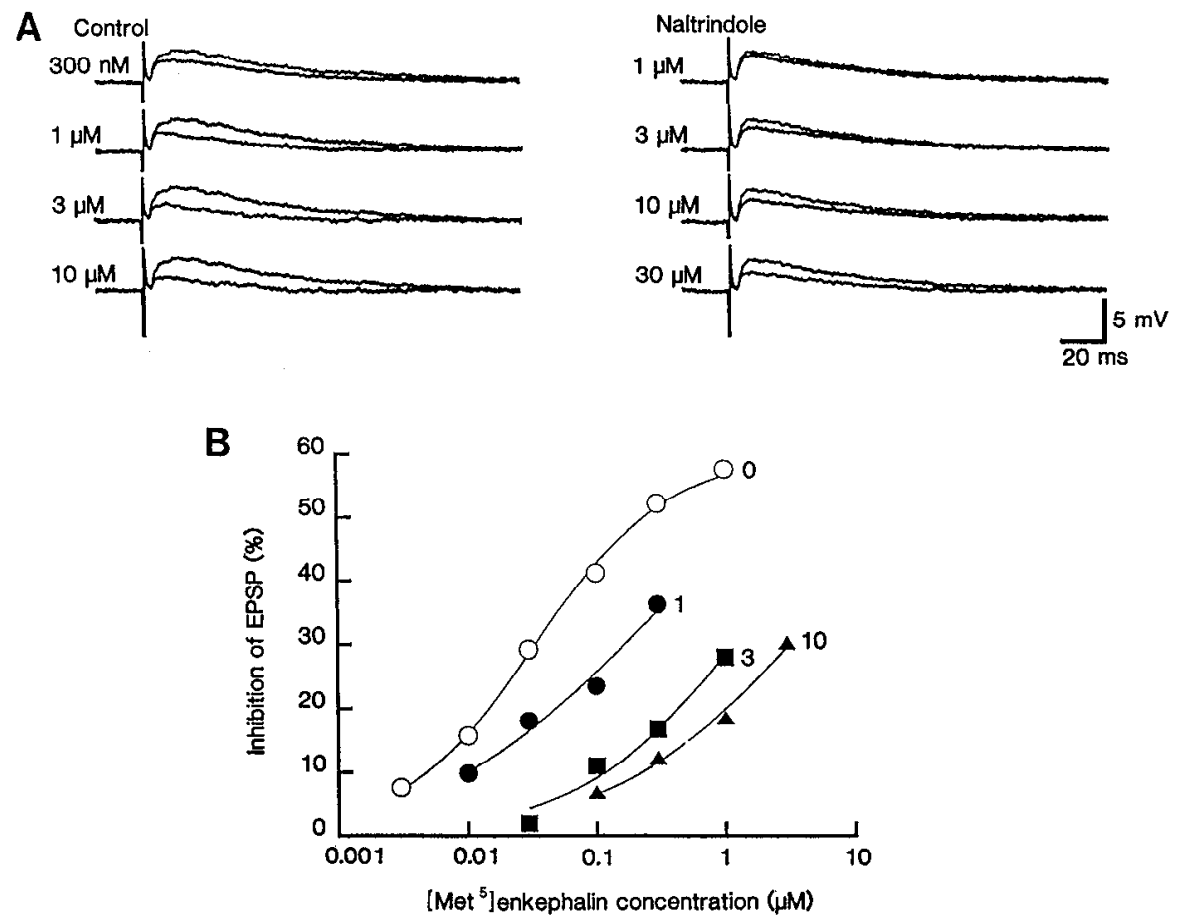
A
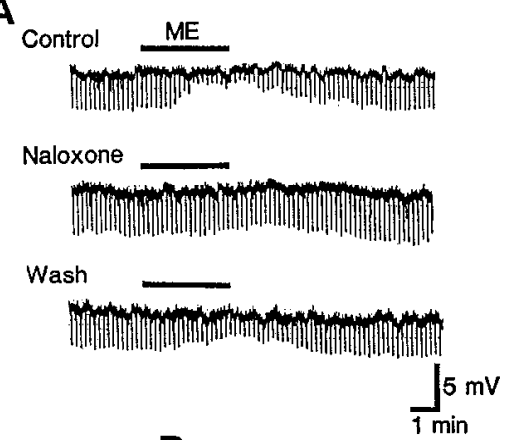

B

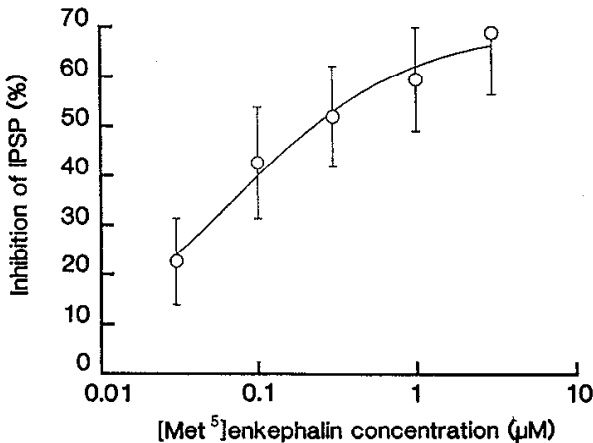

Figure 4. [Met $\left.{ }^{5}\right]$ enkephalin inhibits the IPSP. $A: L e f t$, Time course of inhibition. Downward deflections are IPSPs. $\left[\mathrm{Met}^{s}\right]$ enkephalin $(M E ; 10 \mu \mathrm{M})$ was applied during the time indicated by the horizontal bar. The middle record shows that the effect of $\left[\mathrm{Met}^{5}\right]$ enkephalin was blocked by naloxone $(1 \mu \mathrm{M})$; the lower record is after the washout of naloxone. Right, Each panel shows the control IPSP supcrimposed on the IPSP in [Met ${ }^{5}$ ]enkephalin $(10 \mu \mathrm{M})$. Each IPSP shown is the average of 10 . Top, Synaptic potentials were reduced by [Met ${ }^{5}$ enkephalin $(M E ; 10 \mu \mathbf{M}, 2 \mathrm{~min})$. Middle, Naloxone blocked the effect of [Met ${ }^{5}$ ]enkephalin. Bottom, Wash of naloxone. Membrane potential, -60 $\mathrm{mV} . B$, Concentration dependence of inhibition. Each point shows the inhibition \pm SD of five to eight cells tested at each concentration. CNQX $(10 \mu \mathrm{M})$ and APV $(50 \mu \mathrm{M})$ were present throughout. Synaptic potentials were evoked by stimulation within layer $\mathrm{V}$.
APV and $10 \mu \mathrm{M}$ CNQX) (Fig. 4). The effect developed within 1-2 min of $\left[\mathrm{Met}^{5}\right]$ enkephalin reaching the recording chamber and fully recovered when the tissue was washed with control solution for 5-15 min. The inhibition of the IPSP continued unchanged during applications of up to $10 \mathrm{~min}$. The lowest concentration tested ( $30 \mathrm{nM}$ ) inhibited the IPSP by $23 \pm 8.7 \%$ $(n=5)$; the concentration giving half-maximal inhibition was about 60 nм (Fig. 4).

The reduction of the fast IPSP by [Met $\left.{ }^{5}\right]$ enkephalin was mimicked by DPDPE (Fig. 5), DADLE, and [D-Ala $\left.{ }^{2}\right]$ deltorphin-II. It was reversibly blocked by naloxone $(1 \mu \mathrm{M})$ (Fig. 4) and nal- trindole (10 $\mathrm{nM}, 20 \mathrm{~min}$ ) (Fig. 6). DPDPE (100 $\mathrm{nM}, 2 \mathrm{~min}$ ) reduced the fast IPSP amplitude by $43 \pm 5.8 \%(n=5)$ of control, DADLE (100 $\mathrm{nm}, 2 \mathrm{~min})$ reduced it by $38 \pm 13.3 \%(n=5)$, and $\left[\mathrm{D}-\mathrm{Ala}^{2}\right]$ deltorphin II (100 nM) reduced it by $73 \pm 1.0 \%(n$ $=4)$. Naloxone $(1 \mu \mathrm{M}, 10 \mathrm{~min})$ reduced the inhibition of the fast IPSP amplitude by [Met ${ }^{5}$ ]enkephalin $(10 \mu \mathrm{M})$ from $48 \pm$ $7.9 \%(n=7)$ to $14 \pm 5.8 \%(n=7)$. Naltrindole $(10 \mathrm{nM}, 20 \mathrm{~min})$ reduced the inhibition of the fast IPSP amplitude by $\left[\mathrm{Met}^{5}\right]$ enkephalin $(10 \mu \mathrm{M})$ from $51 \pm 7.9 \%(n=6)$ to $27 \pm 2.9 \%$ $(n=6)$. The apparent dissociation constant for naltrindole was $0.15 \pm 0.13 \mathrm{nM}(n=8)$. No reduction of the fast IPSP amplitude
A
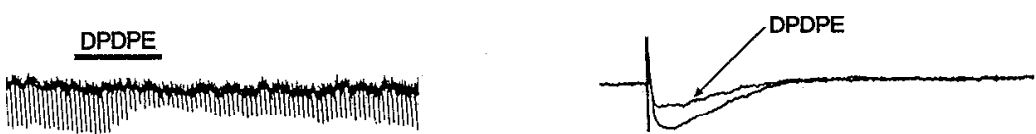

B

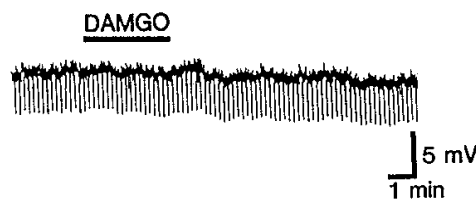

Control

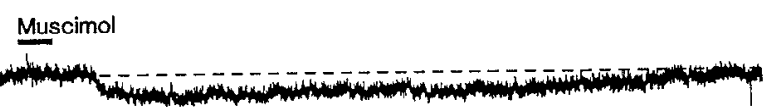

ME

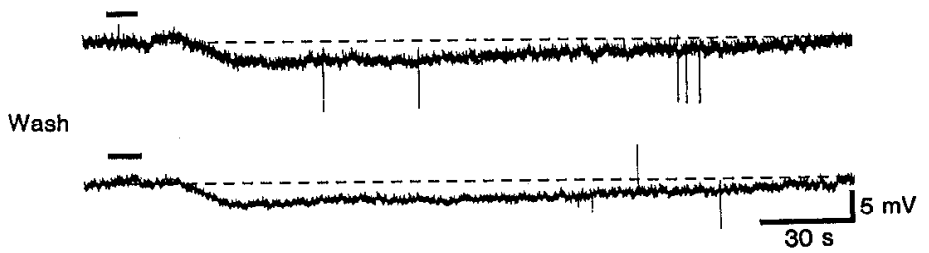

Figure 5. $\delta$-Receptor-selective agonist inhibits the IPSP. $A$, DPDPE $(1 \mu \mathrm{M})$ but not DAMGO $(1 \mu \mathrm{M})$ reduced IPSP amplitude. Details are as in Figure 1. Membrane potential was held at -55 $\mathrm{mV}$. $B$, Hyperpolarization evoked by muscimol $(5 \mu \mathrm{M}, 10 \mathrm{sec})$ is unaffected by $\left[\mathrm{Met}^{5}\right]$ enkephalin. Top, Control. Middle, In [Met ${ }^{s}$ ]enkephalin $(M E ; 10$ $\mu \mathrm{M})$. Bottom, Wash. Membrane potential was held at $-55 \mathrm{mV}$. CNQX (10 $\mu \mathrm{M})$ and APV $(50 \mu \mathrm{M})$ were present. Synaptic potentials were evoked by stimulation within layer $\mathrm{V}$. 
Figure 6. Naltrindole competitively antagonizes inhibition of IPSP (recordings from a single cell). $A$, Each panel shows two superimposed traces (each the average of 10 IPSPs) before and after adding DADLE. Left, Effect of increasing concentrations of DADLE. Right, Repeated in the presence of naltrindole $(10 \mathrm{nM}) . B$, The effects of DADLE applied to this cell on 19 occasions. Numbers beside the traces indicate the concentration of naltrindole present (nM). CNQX $(10 \mu \mathrm{M})$ and APV $(50 \mu \mathrm{M})$ were present throughout.
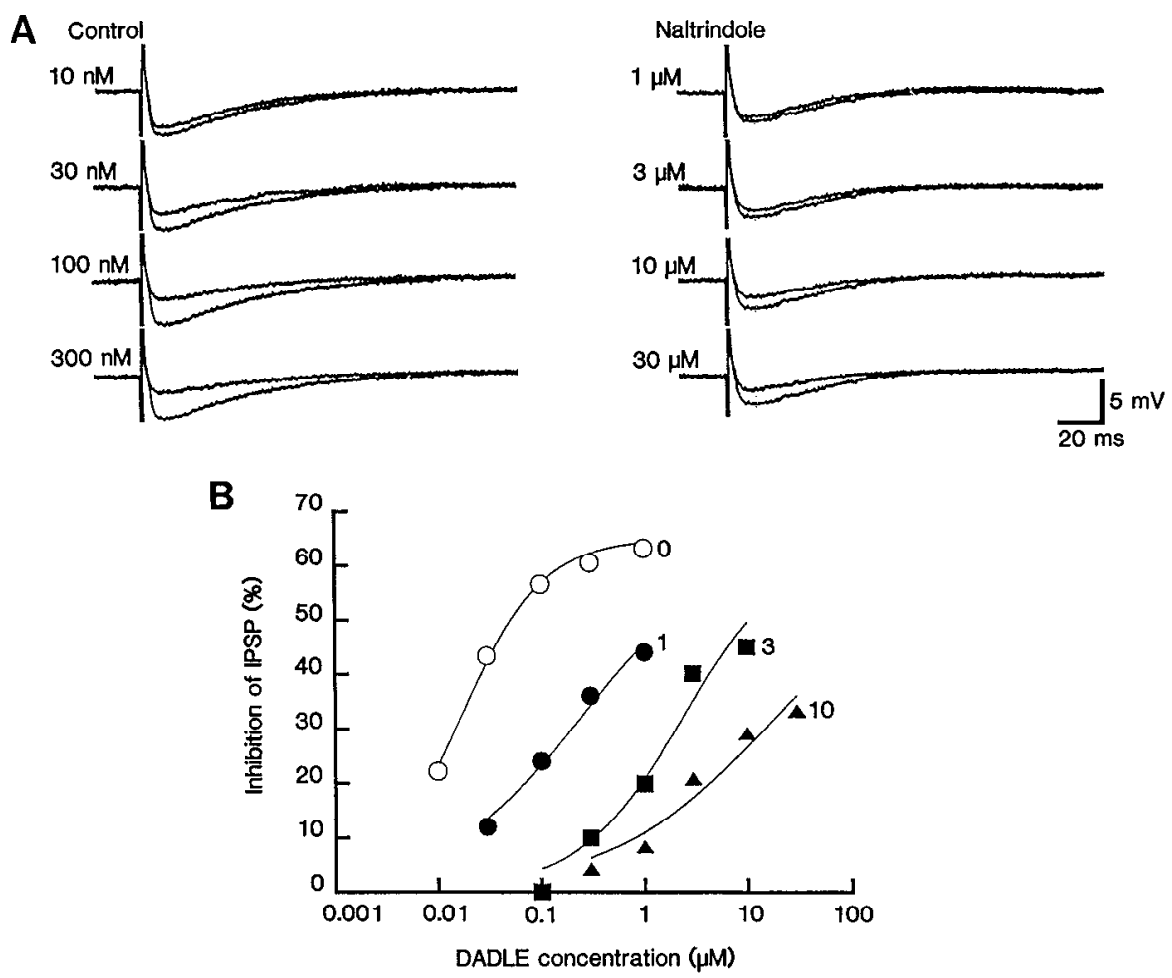

was seen with DAMGO (300 nM) (Fig. 4) or U50488 (1 $\mu \mathrm{M})(n$ $=5$ in each case), and CTOP (300 nM) did not affect the inhibition observed with [Met ${ }^{5}$ enkephalin $(10 \mu \mathrm{M})$.

Muscimol was applied by brief superfusion $(5 \mu \mathrm{M}, 10 \mathrm{sec})$ and it evoked a hyperpolarization of $5-10 \mathrm{mV}$ (membrane potential held at $-55 \mathrm{mV})$. [Met $\left.{ }^{5}\right]$ enkephalin $(10 \mu \mathrm{M})$ did not affect the response to muscimol $(n=5)$ (Fig. 5). The same results were obtained with $(n=3)$ or without $(n=2)$ APV $(50 \mu \mathrm{M})$ and
CNQX $(10 \mu \mathrm{M})$, and with $(n=3)$ or without $(n=2)$ TTX (1 $\mu \mathrm{M})$.

\section{Direct postsynaptic actions of [Met $\left.{ }^{5}\right]$ enkephalin}

[Met ${ }^{5}$ ]enkephalin ( $300 \mathrm{nM}$ to $30 \mu \mathrm{M}$ ) hyperpolarized 22 of 45 pyramidal neurons tested and had no effect on 23 pyramidal neurons. The hyperpolarization persisted in TTX $(1 \mu \mathrm{M})$, which blocked action potentials and synaptic potentials. The hyper-
Figure 7. Hyperpolarization of pyramidal neuron by [Met ${ }^{5}$ ]enkephalin mediated by $\delta$-receptors. $A$ and $B$, [Met ${ }^{5}$ ]enkephalin-induced hyperpolarization was blocked by naloxone $(1 \mu \mathrm{M})$ and naltrindole $(10 \mathrm{~nm})$. In each experiment, [Met ${ }^{5}$ ]enkephalin $(10 \mu \mathrm{M})$ was applied before, in the presence of, and $40 \mathrm{~min}$ after washing out the antagonist. $C$, DAMGO $(1 \mu \mathrm{M})$ had no effect on membrane potential but DPDPE (1 $\mu \mathrm{M})$ hyperpolarized the cell and decreased input resistance. Downward deflections are electrotonic potentials resulting from currents of $120 \mathrm{pA}$ for $200 \mathrm{msec}$ applied at $0.2 \mathrm{~Hz}$.
A

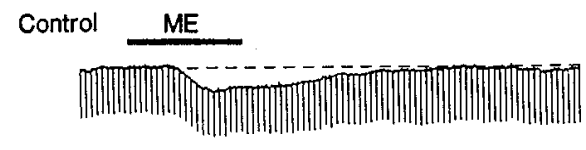

Naloxone

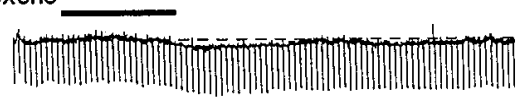

Wash

C

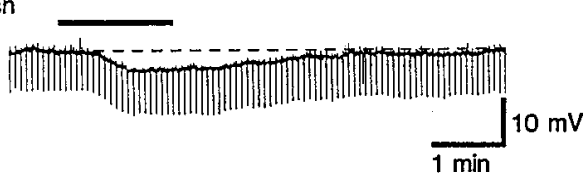

Wash

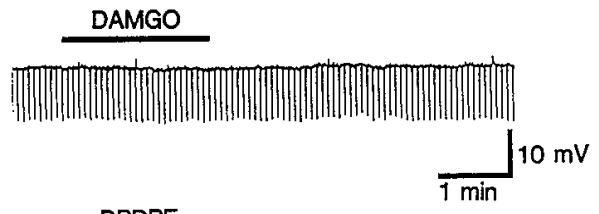

DPDPE

B

Control

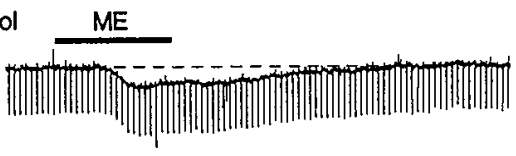

Naltrindole
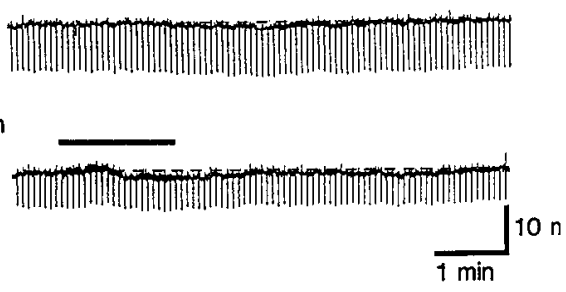

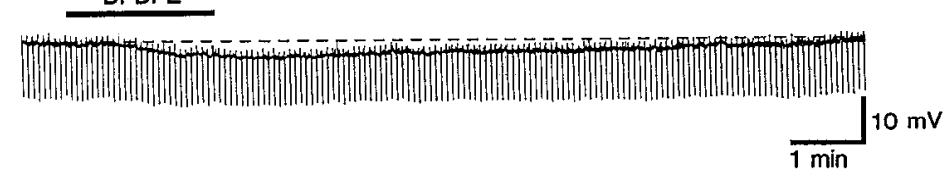


A

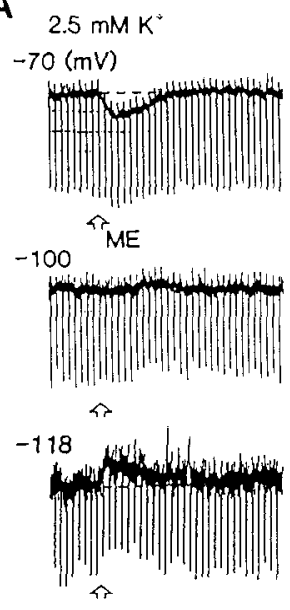

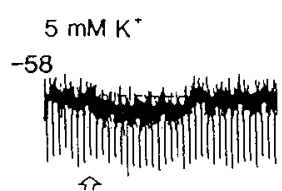

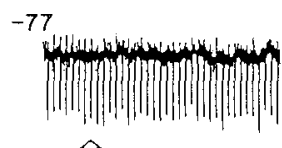

个

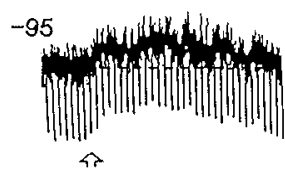

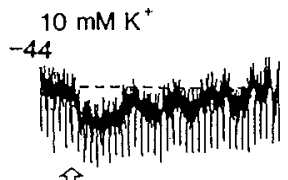

$-60$
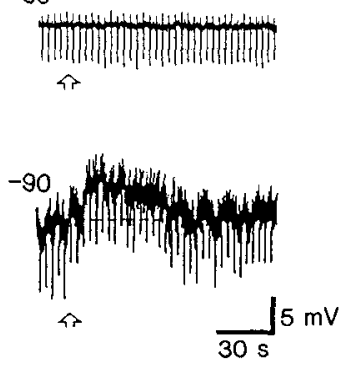

B

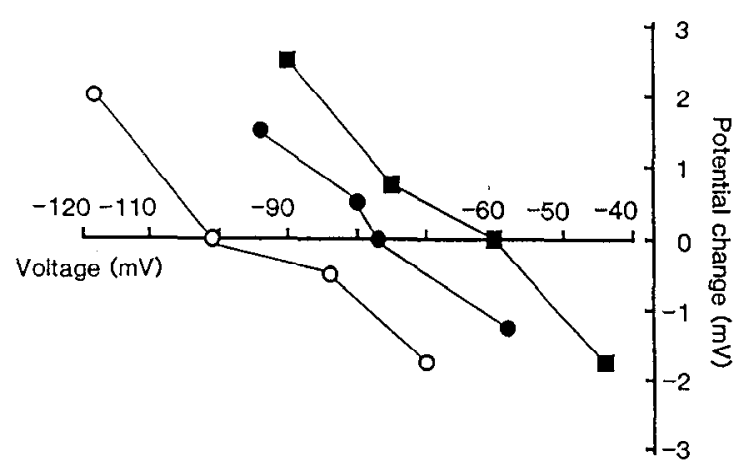

Figure 8. [Met ${ }^{5}$ ]enkephalin increases potassium conductance of a pyramidal neuron. $A$, $\left[\mathrm{Met}^{5}\right]$ enkephalin (open arrow, $140 \mathrm{kPa}$ for $30 \mathrm{msec}$ applied to pipette containing $10 \mathrm{~mm}$ ) was applied in different concentrations of extracellular potassium (left to right) and at different membrane potentials (top to bottom). $B$, Voltage dependence of $\left[\mathrm{Met}^{5}\right.$ ]enkephalin-induced potential change, at the three [Met $\left.{ }^{5}\right]$ enkephalininduced potential change, at the three potassium concentrations.

polarization was associated with a decrease in cell input resistance. The amplitude of the hyperpolarizing response became larger when the neuron was held at a depolarized level, and smaller when applied to a hyperpolarized cell. With extracellular potassium concentration $\left(\left[\mathrm{K}^{+}\right]_{o}\right)$ of $2.5 \mathrm{mM}$, the [ $\left.\mathrm{Met}^{5}\right]$ enkephalinmediated hyperpolarization reversed in polarity at $-103 \pm 5.5$ $\mathrm{mV}(n=4)$. When $\left[\mathrm{K}^{+}\right]$。 was $5 \mathrm{~mm}$ and $10 \mathrm{~mm}$ these values were $-85 \pm 1.7 \mathrm{mV}(n=4)$ and $-66 \pm 3.1 \mathrm{mV}(n=4)$, respectively (Fig. 8). This corresponds to a change of $61 \mathrm{mV}$ for a 10-fold change in $\left[\mathrm{K}^{+}\right]_{\circ}$ (Fig. 8). DPDPE (100 nM to $3 \mu \mathrm{M}$ ) hyperpolarized all pyramidal neurons that were hyperpolarized by $\left[\mathrm{Met}^{5}\right]$ enkephalin $(n=5)$ (Fig. 7$)$, and this was also concentration dependent. DAMGO (up to $3 \mu \mathrm{M}$ ) had no effect on the membrane potential of pyramidal neurons. Naloxone $(1 \mu \mathrm{M})$ and naltrindole $(10 \mathrm{~nm})$ reversibly blocked the membrane hyperpolarization by $\left[\mathrm{Met}^{5}\right]$ enkephalin $(10 \mu \mathrm{M})$ (Fig. 7).

[Met ${ }^{5}$ ]enkephalin $(1-10 \mu \mathrm{M})$ hyperpolarized five of seven nonpyramidal neurons (sparsely spiny cell) tested and had no effect on two nonpyramidal neurons. The hyperpolarization persisted in TTX $(1 \mu \mathrm{M})$ and was associated with a decrease in cell input resistance. DAMGO (100 nM to $3 \mu \mathrm{M})$ also caused a concentration-dependent hyperpolarization of all five nonpyramidal neurons, but DPDPE (up to $3 \mu \mathrm{M}$ ) had no effect $(n=5$ ). CTOP ( 300 nM) reversibly blocked the membrane hyperpolarization by [Met ${ }^{5}$ ]enkephalin (10 $\left.\mu \mathrm{M}\right)$ (Fig. 9).

\section{Discussion}

Presynaptic inhibition of the EPSP and the IPSP

Both NMDA and non-NMDA components of the EPSP, as well as the $\mathrm{GABA}_{\mathrm{A}}$ receptor-mediated IPSP, were inhibited by opioids. These effects were observed in pyramidal cells in which there was no change in membrane potential or input resistance. The reduction of EPSPS and IPSP showed little decline with prolonged applications, but reversed readily when the $\left[\mathrm{Met}^{5}\right]$ enkephalin was washed out. [Mct $\left.{ }^{5}\right] \mathrm{enkephalin}$ did not change the depolarization evoked by direct application of glutamate or the hyperpolarization evoked hy direct application of muscimol. These results are most simply interpreted to indicate that $\left[\mathrm{Met}^{5}\right]$ enkephalin presynaptically inhibits the release of glutamate and GABA.

Considerable evidence supports the conclusion that the opioid receptor type involved in this presynaptic inhibition is a $\delta$-receptor. This includes the mimicry of the action of [Met ${ }^{5}$ ]enkephalin by DPDPE and [D-Ala ${ }^{2}$ deltorphin-II, and the lack of effect of DAMGO and U50488. In similar experiments on mammalian neurons in vitro, DPDPE and DAMGO show virtually complete selectivity for $\delta$ - and $\mu$-receptor subtypes at these concentrations (North et al., 1987). The evidence also includes the block of the effect by naltrindole at low nanomolar concentrations. Considerable errors are associated with the estimates of the dissociation equilibrium constant $\left(K_{D}\right)$ for naltrindole because complete observations with many antagonist concentrations could rarely be made in a single cell (c.g., Figs. $5,6)$, and we therefore used an estimate based upon a single naltrindole concentration and the assumption of competitive antagonism. The estimates are close to those reported by others for $\delta$-receptors (Portoghese et al., 1988), and there was no difference between these estimates of the $K_{D}$ values for the inhibition of the EPSP and the IPSP.

Presynaptic inhibition of the release of excitatory amino acids 
A

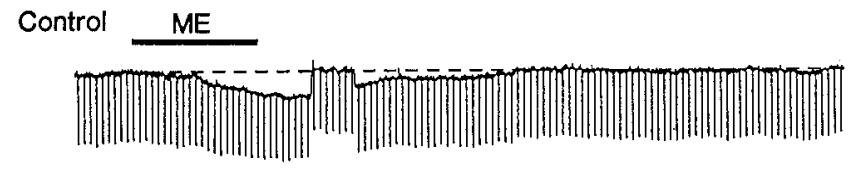

CTOP

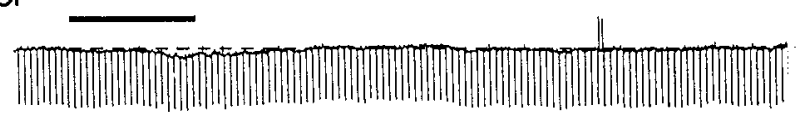

Figure 9. Hyperpolarization of nonpyramidal neuron by [ $\left.\mathrm{Met}^{5}\right]$ enkephalin mediated by $\mu$-receptors. $A$, [Met $\left.{ }^{5}\right]$ enkephalin-induced hyperpolarization, and accompanying decrease in resistance, was blocked by CTOP. Top, Control. Middle, In CTOP (300 nм). Bottom, Wash (after $40 \mathrm{~min}$ ). $B$, DAMGO $(3 \mu \mathrm{M})$, but not DPDPF. ( $3 \mu \mathrm{M})$, caused a hyperpolarization with decreased resistance. Downward deflections are electrotonic potentials caused by passing current pulses of $110 \mathrm{pA}$ for $200 \mathrm{msec}$ across the cell membrane at $0.2 \mathrm{~Hz}$. In the experiments shown in the top trace of $A$ and the bottom trace of $B$, the membrane potential was restored to its original level by passing a sustained current for about $30 \mathrm{sec}$.

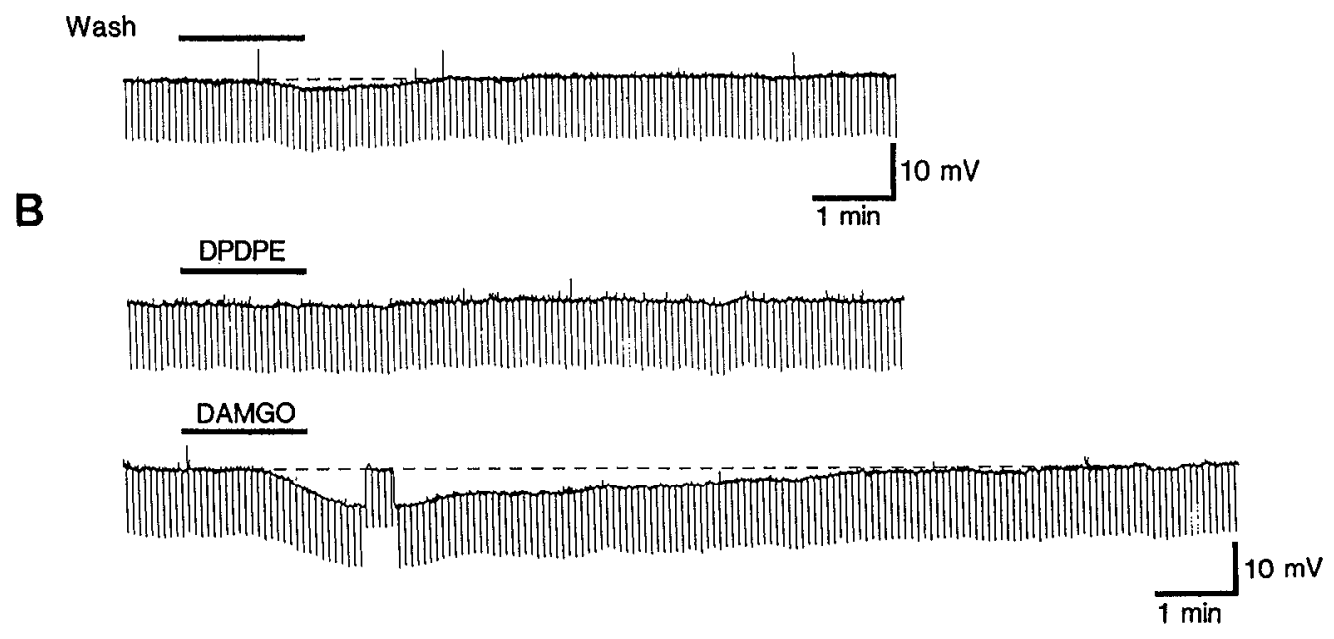

through $\delta$-receptors has previously been reported for the rat striatum (Jiang and North, 1992; Yuan et al., 1992); in that case $\mu$-selective agonists are also effective, raising the possibility that the same presynaptic fibers have both types of receptor. Inhibition of release of excitatory amino acids by activation of $\mu$-receptors is also seen in the dorsal horn of the rat spinal cord (Hori et al., 1992) and rat dentate granule cells (Xie et al., 1992) and by $\kappa$-receptors in the rat locus ceruleus (McFadzean et al., 1987) and guinea pig dentate gyrus (Wagner et al., 1992). The rat anterior cingulate cortex is unusual in that the presynaptic inhibition of glutamate release is exclusively through $\delta$-receptors. The origin of the glutamate-containing fibers is not known. Some of them may arise from other pyramidal cells, which would be consistent with our observation that about half of the pyramidal cells express $\delta$-receptors, as detected by the somatic hyperpolarization.

Presynaptic inhibition of the release of GABA also resulted from $\delta$-receptor activation, as previously reported for the rat striatum (Jiang and North, 1992), lateral amygdala (Sugita and North, 1993), and dentate gyrus (Piguet and North, 1993). The anterior cingulate cortex again differs from those sites in that only $\delta$-selective agonists were effective, not both $\delta$ - and $\mu$-agonists. The origin of the inhibitory GABA-releasing fibers is not known for certain; however, the stimulating electrodes were placed within layer $\mathrm{V}$, so it is reasonable to assume that local interneurons were being excited. Such local interneurons may be a different population from those directly hyperpolarized by opioids, because the hyperpolarization of nonpyramidal cells was apparently mediated by a $\mu$-receptor rather than a $\delta$-receptor (see below). However, it is also possible that a group of interneurons express $\mu$-receptors on their somata, through which hyperpolarization occurs, and $\delta$-receptors on their terminals through which inhibition of transmitter release is mediated.
There was a difference of about 10 -fold between the concentrations of $\left[\mathrm{Met}^{\mathrm{s}}\right]$ enkephalin that inhibited the EPSP and those that inhibited the IPSP. One possibility is that [ $\left.\mathrm{Met}^{5}\right]$ enkephalin is more susceptible to degradation as it diffuses to the excitatory terminals as compared to inhibitory terminals; this would imply a very discrete localization of degradative enzymes. A second possibility is that the mechanism by which release is inhibited may be different. For example, the IPSP may be reduced not only because of an action near the terminals but also because hyperpolarization of the cell bodies within the slice reduces their excitability. Third, the receptor reserve may differ for the two sets of neurons. Fourth, the result may indicate distinct subtypes of $\delta$-receptor on the glutamate- and GABA-releasing nerve terminals. If this is so, then they do not differ markedly in their affinity for naltrindole; there was no difference between our estimates of the $K_{D}$ for the receptors involved in EPSP and IPSP inhibition. There is evidence for the existence of $\delta$-receptor subtypes (Sofuoglu et al., 1991); the isolation of a $\delta$-receptor cDNA clone (Evans et al., 1992; Kieffer et al., 1992) will now allow the subtypes to be definitively identified, and the distribution of their RNAs to be determined at the cellular level in the cortex and other tissues.

The direct action of $\left[\mathrm{Met}^{5}\right]$ enkephalin on about one-half of pyramidal cells was a hyperpolarization that resulted from activation of $\delta$-receptors. As in other neurons (guinea pig submucous plexus, Mihara and North, 1986; rat dentate granule cells, Piguet and North, 1993), this resulted from an increase in membrane potassium conductance. The finding is consistent with the presence $\delta$-opioid binding sites in layer $\mathrm{V}$ of the rat anterior cingulate cortex (Mansour et al., 1987, 1988; Blackburn et al., 1988); presumably a subset of layer V pyramidal cells will contain $\delta$-receptor mRNA. A striking finding of the present work was that nonpyramidal cells, histologically identified, were also 
hyperpolarized but in this case an agonist selective for $\mu$-rather than $\delta$-receptors was effective. Although the sample of cells is small, the results strongly suggest that layer $\mathrm{V}$ interneurons express $\mu$-receptors. This result is in agreement with the presence $\mu$-opioid binding sites in layer $\mathrm{V}$ of the rat anterior cingulate cortex (Mansour et al., 1988). Hyperpolarization of nonpyramidal cells by $\mu$-receptor agonists has also been described in the CA1 region of the hippocampus (Madison and Nicoll, 1988).

In summary, $\left[\mathrm{Met}^{5}\right]$ enkephalin directly reduces the excitability of pyramidal cells and nonpyramidal cells through distinct opioid receptor types by membrane hyperpolarization. A further indirect action is to inhibit the release of excitatory amino acids and of GABA. Both these latter actions involve $\delta$-receptors, but the inhibition of the EPSP is less sensitive to $\left[\mathrm{Met}^{5}\right.$ ]enkephalin than the inhibition of the IPSP. The interplay of these actions presumably underlies the complex effects of iontophoretically applied [ $\mathrm{Met}^{5}$ ]enkephalin and its analogs, as well as morphine, on the firing of neocortical neurons (Williams and Zieglgänsberger, 1981; Janiri et al., 1988; Stanzione et al., 1989).

\section{References}

Blackburn TP, Cross AJ, Hille C, Slater P (1988) Autoradiographic localization of delta opiate receptors in rat and human brain. Neuroscience 27:497-506.

Cohen GA, Doze VA, Madison DV (1992) Opioid inhibition of GABA release from presynaptic terminals of rat hippocampal interneurons. Neuron 9:325-335.

DiChiara G, North RA (1992) Neurobiology of opiate abuse. Trends Pharmacol Sci 13:185-193.

Duggan AW, Fleetwood-Walker SM (1992) Opioids and sensory processing in the central nervous system. In: Handbook of experimental pharmacology (Herz A, Akil H, Simon EJ, eds), pp 731-772. Berlin: Springer.

Duggan AW, North RA (1984) Electrophysiology of opioids. Pharmacol Rev 35:219-281.

Evans CJ, Keith DE Jr, Morrison H, Magendzo K, Edwards RH (1992) Cloning of a delta opioid receptor by functional expression. Proc Natl Acad Sci USA 89:12048-12052.

Iori Y, Endo K, Takahashi T (1992) Prcsynaptic inhibitory action of enkephalin on excitatory transmission in superficial dorsal horn of rat spinal cord. J Physiol (Lond) 450:673-685.

Illes P (1989) Modulation of transmitter and hormone release by multiple neuronal opioid receptors. Rev Physiol Biochem Pharmacol 112:139-233.

Janiri L, d'Amato R, Zieglgansberger W (1988) Dynorphin 1-17 reduces the inhibitory action of mu- and delta-selective opioid agonists in cortical neurons of the rat in vivo. Neurosci Lett 84:79-83.

Jiang ZG, North RA (1992) Pre- and post-synaptic inhibition by opioids in rat striatum. $\mathrm{J}$ Neurosci 12:356-361.

Johnson SW, North RA (1992) Opioids excite dopamine neurons by hyperpolarization of local interneurons. J Neurosci 12:483-488.

Kieffer BL, Befort K, Gaveriaux-RuffC, Hirth CG (1992) The $\delta$-opioid receptor: isolation of a cDNA by expression cloning and pharmacological characterization. Proc Natl Acad Sci USA 89:12048-12052.
Koob GF (1992) Drugs of abuse: anatomy, pharmacology and function of reward pathways. Trends Pharmacol Sci 13:177-184.

Krnjevic K (1965) Actions of drugs on single neurones in the cerebral cortex. Br Med Bull 21:10-14.

Madison DV, Nicoll RA (1988) Enkephalin hyperpolarizes interneurones in the rat hippocampus. J Physiol (Lond) 398:123-130.

Mansour A, Watson SJ (1992) Anatomical distribution of opioid receptors in mammalians: an overview. In: Handbook of experimental pharmacology (Herz A, Akil H, Simon EJ, eds), pp 79-106. Berlin: Springer.

Mansour A, Khachaturian H, Lewis ME, Akil H, Watson SJ (1987) Autoradiographic differentiation of mu, delta, and kappa opioid receptors in the rat forebrain and midbrain. J Neurosci 7:2445-2464.

Mansour A, Khachaturian H, Lewis ME, Akil H, Watson SJ (1988) Anatomy of CNS opioid receptors. Trends Neurosei 11:308-314

McFadzean I, Lacey MG, Hill RG, Henderson G (1987) Kappa opioid receptor activation depresses excitatory synaptic input to rat locus cocrulcus neurons in vitro. Neuroscience 20:231-239.

McGinty JF, Van Der Kooy D, Bloom FE (1984) The distribution and morphology of opioid peptide immunoreactive neurons in the cerebral cortex of rats. J Neurosci 4:1104-1117.

Mihara S, North RA (1986) Opioids increase potassium conductance by activating $\delta$-receptors in submucous neurones of guinea pig caecum. Br J Pharmacol 88:315-322.

North RA (1992) Opioid actions on membrane ion channels. In: Handbook of experimental pharmacology (Herz A, Akil H, Simon EJ, eds), pp 773-797. Berlin: Springer.

North RA, Williams JT, Surprenant A, Christie MJ (1987) $\mu$ and $\delta$ opioid receptors both belong to a family of receptors that are coupled to potassium channels. Proc Natl Acad Sci USA 84:5487-5491.

Piguet P, North RA (1993) Opioid actions at $\mu$ and $\delta$ receptors in the rat dentate gyrus in vitro. J Pharmacol Exp Ther, in press.

Portoghese PS, Sultana M, Takemori AE (1988b) Naltrindole, a highly selective and potent non-peptide $\delta$ opioid receptor antagonist. Eur J Pharmacol 146:185-186.

Sofuoglu M, Portoghese PS, Takemori AE (1991) Differential antagonism of delta opioid agonists by naltrindole and its benzofuran analog (NTB) in mice: evidence for delta opioid receptor subtypes. $\mathbf{J}$ Pharmacol Exp Ther 257:676-680.

Stanzione P, Stefani A, Calabresi P, Mercuri NB, Bernardi G (1989) Met- and leu-enkephalins inhibit rat cortical neurons intracellularly recorded in vivo while morphine excites them: evidence for naloxonesensitive and naloxone-insensitive effects. Fxp Brain Res 77:302-308.

Sugita S, North RA (1993) Opioid actions on neurons of rat lateral amygdala in vitro. Brain Res 612:151-155.

Tanaka E, North RA (1993) Actions of 5-hydroxytryptamine on neurons of the rat cingulate cortex. J Neurophysiol 69:1749-1757.

Wagner JJ, Caudle RM, Chavkin C (1992) Kappa-opioids decrease excitatory transmission in the dentate gyrus of the guinea pig hippocampus. J Neurosci 12:132-141.

Williams JT, Zieglgänsberger W (1981) Neurones in the frontal cortex of the rat carry multiple opiate receptors. Brain Res 226:304-308.

Xie CW, Morrisett RA, Lewis DV (1992) Mu opioid receptor-mediated modulation of synaptic currents in dentate granule cells of rat hippocampus. J Neurophysiol 68:1113-11120.

Yuan X, Madamba S, Siggins GR (1992) Opioid peptides reduce synaptic transmission in the nucleus accumbens. Neurosci Lett 134: 223-228.

Zieglgänsberger W, French ED, Siggins GR, Bloom FE (1970) Opioid peptides may excite hippocampal pyramidal neurons by inhibiting adjacent inhibitory interneurons. Science 205:415-417. 